\title{
REGULATION OF OFFSHORE INVESTMENT COMPANIES THROUGH EXTRATERRITORIAL APPLICATION OF RULE 10b-5
}

The managerial and financial structure of investment companies provides strong incentives for internal corporate inanipulation. Although investment company shareholders receive inost rights associated with corporate ownership, ${ }^{1}$ the typical shareholder is financially unable to purchase an influential interest. ${ }^{2}$ The large size of investinent companies and the middle-incoine clients to whoin they cater encourage corporate control by a small group of investors. ${ }^{3}$ The controlling shareholders of an investinent company influence the coinpany's decisions regarding investment of its highly liquid assets, possibly favoring their own interests and ignoring the interests of noncontrolling shareholders. ${ }^{4}$ In recognition of these potential abuses, Congress enacted the Investment Company Act of 1940 (ICA) ${ }^{5}$ and the Investment

1. For an example of the rights granted to shareholders of an investment company, see the explanatory memorandum concerning a fictional-Luxembourg investment company's offer of shares im Practicing Law Institute, Investment PaRtnerships and OFFshore Investment Fund 109-39 (1969).

2. See Securities and Exchange Commission, Abuses and Deficiencies in the ORGANIZATION AND OPERATION OF INVESTMENT TRUSTS AND INVESTMENT COMPANIES, H.R. DOC. No. 279, 76th Cong., 1st Sess. 31 (1940) [heremafter cited as SEC ABUSES REPORT]

3. For a thorough description of the structure of an offshore investment company, see SECURITIES AND Exchange Commission, InSTITUTIONAL INVESTOR STUDY, H.R. Doc. No. 64, pt. 3, 92d Cong., Ist Sess. (1971) [hereinafter cited as INSTITUTIONAL INVESTOR STUDY]. See also Securities and Exchange Commission, The Origin, Scope, and Conduct of the Study, Nature, and Classification of INVEstment TRUSTS and INVESTMENT CoMpanies, and the ORIGIN OF THE INVESTMENT TRUST AND INVESTMENT COMPANY MOVEMENT IN THE UNITED StaTES, H.R. Doc. No. 707, 75th Cong., 3d Sess. (1940) [hereimafter cited as INVESTMENT CoMPANY REPORT].

4. Commentimg on the period after the stock market collapse in 1929 , the SEC noted that

[imvestment company] insiders often sold unmarketable securities . . . to their investment compames or caused these companies to take over dubious and illiquid investments in which they were imterested; compelled these organizations to assume large and onerous commitments on which these insiders were obligated, such as participations in underwritings, trading accounts, loans, and other commitments; required these companies to relieve them of existing liabilities and obligations to their investment companies; caused these organizations to finance clients of these insiders and companies in which they were imterested; and induced the making of direct loans to insiders, often without any collateral or upon inadequate security. These various transactions were permeated with conflicting interests, and inany were characterized by the absence of arm's-length dealing and by opportunities for overreaching.

SEC ABUSES REPORT, supra note 2, at 22.

5. 15 U.S.C. $\$ \S 80 \mathrm{a}-1$ to -52 (1976). 
Advisers Act of 1940 (IAA). ${ }^{6}$ Both Acts require disclosure of specific financial data ${ }^{7}$ and restrict activities of persons affiliated with investment companies. ${ }^{8}$

Since the enactment of the ICA and the IAA, several foreign investment companies have been created to avoid both United States tax and securities regulations ${ }^{9}$ and the restraints of the ICA and the IAA. The ICA and the IAA regulate only those conpanies that register under the Acts or use instrumentahities of interstate commerce to sell securities. ${ }^{10}$ Because neither the ICA nor the IAA regulate "offshore" investment companies, claims against those conipanies require extraterritorial application of other federal securities laws.

In IIT v. Cornfeld " the Court of Appeals for the Second Circuit extended rule $10 b-5^{12}$ extraterritorially to exercise subject-matter jurisdiction in an action brought by foreign shareholders of a foreign investment company against its foreign investment advisers. The court's decision impermissibly extends federal securities laws because it permits regulation of the internal affairs of offshore investınent conıpanies in a manner similar to regulation of domestic investment companies under the ICA and the IAA.

This note analyzes the Second Circuit's use of rule $10 \mathrm{~b}-5$ to regulate the internal affairs of offshore investinent companies. The Cornfeld decision represents the intersection of two trends in interpretation of federal securities regulation: first, the shift fron a strictly disclosure-based application of rule $10 \mathrm{~b}-5$ to a broader corporate mismanagenent-fiduciary duty interpretation; ${ }^{13}$ and second, the development of the "conduct" and "effects" tests for extraterritorial application of federal securities laws. ${ }^{14}$ This note discusses the developnient of

6. Id. $\$ 880 \mathrm{~b}-1$ to -21 .

7. For example, investment companies that register under the ICA must file a statement that discloses the extent to which the company intends to borrow money, issue senior securities, underwrite securities, concentrate investment im specific industries, purchase and sell real estate or commodities, make loans to other persons, and turn over its portfoho. 15 U.S.C. \& 80a-8(b)(1) (1976).

8. The ICA prohibits any person affiliated with an investment company from selling securities to that company or from participating jomitly with the company in any transaction with other persons. 15 U.S.C. \& 80a-17(a), (d) (1976). See notes 54-62 infra and accompanying text.

9. See InSTITUTIONAL INVESTOR STUDY, supra note 3, at 885 .

10. See 15 U.S.C. $\$ \S 80 \mathrm{a}-7,80 \mathrm{~b}-4,-6$ (1976).

11. 619 F.2d 909 (2d Cir. 1980).

12. 17 C.F.R. $\& 240.10 b-5$ (1981) (promulgated pursuant to section $10(b)$ of the Securities Exchange Act of 1934, 15 U.S.C. \& 78j(b) (1976)).

13. Compare Santa Fe Indus., Inc. v. Green, 430 U.S. 462 (1977) with Goldberg v. Meridor, 567 F.2d 209 (2d Cir. 1977), cert. denied, 434 U.S. 1069 (1978).

14. See generally IIT v. Vencap, Ltd., 519 F.2d 1001 (2d Cir. 1975); Schoenbauin v. Firstbrook, 405 F.2d 200 (2d Cir.), rev'd with respect to holding on merits, 405 F.2d 215 (2d Cir. 1968) (en banc), cert. denied, 395 U.S. 906 (1969). 
both trends and analyzes the Second Circuit's use of these concepts to support jurisdiction, focusing on the effect of such use on the ICA and the IAA.

\section{IIT $v$. CORNFELD: INTERNAL Mismanagement OF OFFshore INVESTMENT COMPANIES}

The liquidators of IIT, an international investment trust organized under Luxembourg law, brought a derivative action in the United States agamst the company's investment adviser, IIT Management Company, alleging several 10b-5 violations. IIT was operated like an open-ended mutual fund: ${ }^{15}$ foreign investors purchased redeemable shares of the IIT "fund," and the fund's assets were nranaged and controlled by IIT Management, a Luxembourg corporation controlled by Investors Overseas Services, Ltd. (IOS). Both IOS and IIT Management were operated from Geneva and controlled by Bernard Cornfeld and, later, by Robert Vesco. ${ }^{16}$

15. Judge Friendly accepted this characterization of IrT's operation in IIT v. Vencap, Ltd., 519 F.2d 1001, 1003 n.1 (2d Cir. 1975). In an "open-ended" inutual fund, the fundholders have an unlimited right to have the investment company redeem their shares at any time. See generally INVESTMENT COMPANY REPORT, supra note 3. Luxeunbourg law prohibits an investment coinpany from purchasing its own shares. Thus, to operate as an open-ended investment company, the company must establish a second company to repurchase independently shares redeened by investors. The investment company lends to the repurchasing company the funds required for the repurchases. To repay the loans, the repurchasing company resells the shares it purchases. INSTITUTIONAL INVESTOR STUDY, supra note 3, at 917. IIT differed froin domestic open-ended companies in that it had no directors. IIT v. Cornfeld, 619 F.2d at 913 n.4.

16. Investors Overseas Services, Ltd., created by Bernard Cornfeld, was an offshore investment service that allowed Europeans to invest in American securities, which the Europeans beheved were less risky than others, but to avoid United States regulation and taxation. During its heyday in early 1970 , IOS employed almost 20,000 people to serve customers in over 125 countries. At that time, the IOS complex included 17 mutual funds, 20 fund management companies, 12 banks and financial companies, 10 real estate companies, and 50 other subsidiaries. It had assets of over \$2 billion. See Note, Offshore Mutual Funds: Possible Solutions to a Regulatory Dilemma, 3 LAW \& POL'Y IN INT'L Bus. 157, 158 n.7 (1971). Of IOS’s $\$ 2$ billion assets, IIT held $\$ 345$ million, of which 40 percent was American securities. In 1971, after the value of IOS's assets dropped by $\$ 1$ billion, IOS cut its staff by one-half, and Cornfeld sold all of his interest in the IOS enterprise. American financier Robert Vesco eventually took control. The large losses and consequential reduction in the inarket value of IOS shares caused massive redemptions of those shares. The SEC's charge in 1972 that Vesco was looting IOS funds hastened the IOS's decline. As a result of the subsequent scandal, Luxenibourg placed all investment funds, including IIT, under the control of the Bank Control Commissioner. One year later, the Luxembourg district court approved the Commissioner's petition for a declaration of IIT's bankruptcy and appointed liquidators, the plaintiffs in IIT v. Cornfeld. 619 F.2d 909, 913 (2d Cir. 1980). The collapse of IOS and its subsidiaries created numerous lawsuits. See, e.g., Arthur Lipper Corp. v. SEC, 547 F.2d 171 (2d Cir. 1976), cert. denied, 434 U.S. 1009 (1978); King v. United States, 545 F.2d 700 (10th Cir. 1976); In re Colorado Corp., 531 F.2d 463 (10th Cir. 1976); Bersch v. Drexel Firestone, Inc., 519 F.2d 974 (2d Cir.), cert. denied, 423 U.S. 1018 (1975); IIT v. Vencap, Ltd., 519 F.2d 1001 (2d Cir. 1975); International Controls Corp. v. Vesco, 490 F.2d 1334 (2d Cir.), cert. denied, 417 U.S. 932 (1974); 
The complaimt alleged that IOS, IIT Management, and a group of American corporations controlled by John King conspired to defraud IIT. Allegedly, IOS and IIT Management, in exchange for kickbacks, inflated management fees, and the opportunity to participate in Kingsponsored tax avoidance schemes, agreed to induce IIT to purchase securities from the King complex. King's companies required "continuous injections of vast sums of money to survive."17

IIT acquired the King securities in three transactions. First, IIT acquired subordinated debentures having a face value of $\$ 8$ million from King Resources Capital Corporation (KRCC). IIT later sold these debentures at a loss of almost $\$ 9$ million. ${ }^{18}$ Second, IIT purchased 200,000 shares of King Resources Company (KRC) stock for $\$ 16.8$ million. IIT later lost $\$ 14$ million in selling the stock. Finally, IIT purchased a $\$ 12$ million convertible note from The Colorado Corporation (TCC). The note was never paid because TCC, along with the other companies of the King coinplex, declared bankruptcy. Because of stays issued in bankruptcy, KRC, TCC, and KRCC were not named defendants in the action. ${ }^{19}$ For the losses allegedly suffered, IIT requested $\$ 35$ million in compensatory damages and $\$ 35$ million in punitive damages.

The threshold issue in the case was whether American courts have subject-matter jurisdiction over a foreign investment adviser's scheine to defraud a foreign investment company. ${ }^{20}$ Because the ICA and the IAA do not apply to foreign imvestment companies, ${ }^{21}$ jurisdiction was available only through extraterritorial application of anti-fraud regulations. ${ }^{22}$ Without subject-matter jurisdiction, the case would have been dismissed, and IIT would have been required to bring its action in Luxembourg, where personal jurisdiction over several American "aider and abettor" defendants could not liave been obtained. ${ }^{23}$

The Court of Appeals for the Second Circuit reversed the district court's dismissal for lack of subject-matter jurisdiction. ${ }^{24}$ Ratlier than

Cornfeld v. Investors Overseas Servs., Ltd., 471 F. Supp. 1255 (S.D.N.Y.), affd mem., 614 F.2d 1286 (2d Cir. 1979); IIT v. Cornfeld, 462 F. Supp. 209 (S.D.N.Y. 1978), rev'd, 619 F.2d 909 (2d Cir. 1980); Venture Fund v. Willkie Farr \& Gallagher, 418 F. Supp. 550 (S.D.N.Y. 1976).

17. 619 F.2d at 915 .

18. Id. at 914.

19. See id. John King was convicted in a criminal action for his activities regarding "Fund of Funds," another IOS-controlled investment fund that speculated in shares of other investment companies. See United States v. King, 560 F.2d 122 (2d Cir.), cert. denied, 434 U.S. 925 (1977).

20. 619 F.2d at 912-13.

21. See, e.g., 15 U.S.C. $\$ \S 80 \mathrm{a}-7,-8,80 \mathrm{~b}-6$ (1976).

22. E.g., Rule 10b-5, 17 C.F.R. $\$ 240.10 \mathrm{~b}-5$ (1981).

23. See 619 F.2d at $917 \&$ n. 10 .

24. Id. at 932. 
viewing the transaction as entirely foreign, the Second Circuit emphasized the domestic activities of the nondefendant King companies and held that those activities provided a sufficient basis for subject-matter jurisdiction. ${ }^{25}$ The court refused to view IIT Management's activities as a breach of fiduciary duty to IIT and instead stated that the activities were relevant only to avoid imputimg IIT Management's knowledge of the fraudulent activities to IIT. ${ }^{26}$ Using this rationale, the court linked IIT Management with the King coinplex's United States activities, asserted subject-1natter jurisdiction based on those activities, exposed IIT Management to 10b-5 liability for its activities, which essentially involved breach of fiduciary duty, and circumvented the jurisdictional restrictions imposed by the ICA and the IAA ${ }^{27}$-Acts applicable to similar activities by domestic imvestment companies and advisers. ${ }^{28}$

The Second Circuit's rationale allows regulation of the internal management of foreign investment companies. This regulation has several negative repercussions. First, foreign investment advisers that breach their fiduciary duty to their clients are subject to $10 \mathrm{~b}-5$ hability so long as the breach involves an American corporation engaging in significant domestic conduct..$^{29}$ Rather than bring a cause of action for breach of fiduciary duty in the foreign country, foreign shareholders may bring the action in the Umited States by claiming that the investment adviser violated rule $10 \mathrm{~b}-5$ and by emphasizing the doinestic activities of the American corporation. Shareholders in countries whose securities laws are less strict than those of the United States will prefer to bring the action in the United States. Thus, Cornfeld increases the jurisdictional scope of Umited States securities laws at the expense of foreign laws that are argnably inore applicable to the foreign transaction.

Second, Cornfeld's rationale ignores the jurisdictional limitations in the ICA and the IAA. Although IIT Manageinent's activities were the specific types of activities proscribed im those Acts, the Acts do not provide a basis for subject-matter jurisdiction because they apply only to domestic investment companies or to domestic activities of investment advisers. ${ }^{30}$ By classifying a foreign investınent adviser's activities as conspiracy with a third-party American company to defraud the imvestment company, the foreign shareholders may bring suit under rule

\footnotetext{
25. Id. at $917-18$.

26. Id.

27. See statutory sections cited at note 21 supra.

28. See notes 57-74 infra and accompanying text.

29. For a discussion of the "conduct" test for subject-matter jurisdiction, see text accompanying notes 128-30 infra.

30. See 15 U.S.C. $\$ 880 a-7,-8,80 b-6$ (1976).
} 
$10 \mathrm{~b}-5$, avoid the jurisdictional limitations of the ICA and the IAA, and obtain relief similar to that provided by those Acts. Thus, the Cornfeld decision allows United States courts to exceed the express jurisdictional limits of the ICA and the IAA and regulate the internal affairs of offshore investment coinpanies to a degree never before achieved.

\section{Statutory Regulation of Investment Companies: The INVESTMENT COMPANY ACT AND THE INVESTMENT \\ ADVISERS ACT}

\section{A. Legislative Purpose.}

The ICA and the IAA are the last of a series of securities regulations enacted in response to the 1929 collapse of the nation's financial nrarkets. ${ }^{31}$ After an exhaustive SEC study revealed widespread and uncontrolled abuses in the investinent company industry, ${ }^{32}$ Congress and representatives of the investinent-conipany and investinent-advisers industries worked jointly to enact the ICA and the IAA.

The Senate Committee on Banking and Currency, recommending passage of the ICA, pointed out several abuses to be reinedied by the legislation. ${ }^{33}$ First, the highly liquid, highly nrobile, and easily negotiable assets of investinent coinpanies were attractive to "unscrupulous manageinents" that used the assets for personal profit to the detriment of the conpanies' shareholders. ${ }^{34}$ Second, investinent conpanies were created with minimal capital and could be controlled by persons previously convicted for securities fraud..$^{35}$ Finally, the potential for selfdealing through unloading worthless securities, causing unfair purchases, obtaining unsecured loans, and making affiliated transactions presented opportunities for widespread abuse. ${ }^{36}$ Congress intended the ICA to remedy these abuses, as well as several others noted in section one of the Act, ${ }^{37}$ through detailed regulation of the internal structure and managennent of investment companies.

Judicial interpretation of the legislative history of the ICA emphasizes the close internal regulation that Congress intended. In Brown $v$.

31. Prior to passage of the ICA and the IAA, Congress enacted both the Securities Act of 1933 and the Securities and Exchange Act of 1934.

32. The list of abuses included self-dealing transactions, misrepresentations to sbareholders, transactions with affiliated companies, improper and fraudulent accounting practices, and general internal mismanagement of investment companies. See S. REP. No. 1775, 76th Cong., 3d Sess. 6 (1940). For a compilation of the reports containing the SEC study, see id. 5.

33. Id. 6.

34. Id.

35. $Y d$.

36. $I d$.

37. See 15 U.S.C. § 80a-1(b) (1976). 
Bullock ${ }^{38}$ the District Court for the Southern District of New York noted the contrast between the detailed internal controls of the ICA and the very narrow disclosure and registration policies of the Securities Act of 1933 and the Securities and Exchange Act of 1934. In Burks v. Lasker ${ }^{39}$ the Supreme Court concluded that the primary function of the ICA is to "impose controls and restrictions on the internal inanagement of investment companies." 40

Congress enacted the IAA as a corollary to the ICA in recognition of the influential and potentially abusive role investment advisers play in the management and control of investment companies. The Senate report accompanying the bill ${ }^{41}$ specified two groups protected by the Act: unsophisticated investors subject to unscrupulous investment-adviser activities ${ }^{42}$ and bona fide investment counselors stigmatized by such activities. ${ }^{43}$ The committee also identified the important "personalized relationship" that exists between the investment adviser and the client as a consideration in enforcing the IAA. ${ }^{44}$ Therefore, Congress intended the IAA not only to regulate investment-adviser activities affecting interstate commerce, national securities exchanges, the national banking system, and the United States economy, ${ }^{45}$ but also to regulate and preserve the fiduciary relationship between investinent advisers and their clients.

The Supreme Court has consistently recognized Congress's intent to provide fiduciary standards for investment advisers. The Court thoroughly analyzed the legislative history of the IAA in $S E C v$. Capital Gains Research Bureau ${ }^{46}$ and concluded that

[t]he Investment Advisers Act of $1940 \ldots$. reflects a congressional recognition "of the delicate fiduciary nature of an investment advisory relationship," as well as a congressional intent to eliminate, or at least to expose, all conflicts of interest which might incline an investment adviser - consciously or unconsciously - to render advice which was not disinterested. ${ }^{47}$

The Supreme Court reconfirmed its recognition of the IAA's emphasis

38. 194 F. Supp. 207 (S.D.N.Y.), affd, 294 F.2d 415 (2d Cir. 1961).

39. 441 U.S. 471 (1979).

40. Id. at 478 (quoting United States v. National Ass'n of Sec. Dealers, 422 U.S. 694, 705 n.13 (1975)).

41. S. ReP. No. 1775, 76th Cong., 3d Sess. 6 (1940).

42. Id. 21.

43. Id.

44. Id. 22.

45. 15 U.S.C. $\S 80 \mathrm{~b}-1$ (1976).

46. 375 U.S. 180 (1963).

47. Id. at 191-92 (footnote omitted) (quoting 2 L. Loss, SeCurIties Regulation 1412 (2d ed. 1961)). 
on fiduciary duty in Transamerica Mortgage Advisors, Inc. v. Lewis, ${ }^{48}$ concluding that the IAA establishes "federal fiduciary standards" to govern the conduct of investment advisers. ${ }^{49}$

Viewed together, the legislative histories of the ICA and the IAA reveal a two-pronged congressional attack on investment coinpany abuse: first, by controlling the structural and nnanagerial aspects of investment companies, the ICA prevents situations conducive to abuse; and second, by creating federal fiduciary standards, the IAA provides strong incentives against abusive, fraudulent activities by investment advisers.

The ICA and the IAA regulate the internal affairs of domestic investment companies to protect unsophisticated investors and to preserve the personal nature of the inherent fiduciary relationships between investment companies and their advisers. Express statutory sections exclude foreign investment companies and foreign investment advisers from the scope of the Acts. ${ }^{50}$ Although investment companies not regulated by the ICA cannot sell their own shares in the United States, the Act does not prevent an offshore fund from purchasing securities of United States corporations for its own portfolio. ${ }^{51}$ Thus, Congress recognized that foreign, nonregistered investınent companies might be involved in transactions with United States corporations, but expressly refused to subject those foreign corporations to ICA and IAA regulation. Congress has continued to refuse to regulate offsliore investment companies despite calls for territorial expansion of the federal securities laws. ${ }^{52}$

The Second Circuit, in IIT v. Cornfeld, ${ }^{53}$ achieved what Congress refused to do. By characterizing IIT Management's actions as a failure to disclose material facts and by ignoring the underlying breach of fiduciary duty, the court circumvented the jurisdictional limitations of the ICA and the IAA and allowed regulation of the internal affairs of IIT, a foreign investment coinpany, in a manner similar to ICA and IAA regulation of doinestic investment companies.

48. 444 U.S. 11 (1979).

49. Id. at 17 (quoting Santa Fe Indus., Inc. v. Green, 430 U.S. 462, 471 n.11 (1977)).

50. See note 21 supra. This statement assumes that the SEC does not grant special permis" sion to register under 15 U.S.C. $\$ 80 \mathrm{a}-7$ (d) (1976), and that the investment adviser is using no instrumentalities of interstate commerce, see $i d$. $\S 80 \mathrm{~b}-6$.

51. See id. $\$ 80 \mathrm{a}-7$.

52. See InSTITUTIONAL INVESTOR STUDY, supra note 3; Note, Offshore Mutual Funds: Extraterritorial Application of the Securities Exchange Act of 1934, 13 B.C. InDUS. \& COM. L. Rev. 1225 (1972).

53. 619 F.2d 909 (2d Cir. 1980). 


\section{B. Application of the ICA and the IAA to IIT v. Cornfeld.}

The acts of fraud and self-dealing allegedly perpetrated by IIT Management represent the types of abuse Congress intended the ICA and the IAA to regulate. IIT Management's activities violated both managerial-oriented sections of the ICA and fiduciary-oriented sections of the IAA.

IIT Management's participation with IIT in the King transactions typifies the activity proscribed by section 17(d) of the ICA, which makes "joint and several" participation by "affiliated persons" in transactions with the investment company an unlawful act. ${ }^{54}$ Investment advisers, such as IIT Management, are included expressly in the definition of affiliated persons. ${ }^{55}$ Rule $17 \mathrm{~d}-1,{ }^{56}$ promulgated pursuant to section 17(d), ${ }^{57}$ requires the investment adviser to file an application with the SEC for permission to engage in "joint enterprises." 58 Because affiliate participation can be not only joint but also joint and several, investment company knowledge of the affiliate's jomt activities is not required. ${ }^{59}$ IIT Management's activities are analogous to those in United States v. Deutsch, ${ }^{60}$ in which an investment adviser violated section 17(d) and rule 17d-1 by influencing an investment company to purchase promissory notes while the adviser received a fifty percent

54. 15 U.S.C. $\S 80 \mathrm{a}-17$ (d) (1976).

55. See id. $\$ 80 \mathrm{a}-2(\mathrm{a})(3)(\mathrm{E})$.

56. 17 C.F.R. \& 270.17d-1 (1981).

57. 15 U.S.C. $\$ 80 \mathrm{a}-17$ (d) (1976).

58. 17 C.F.R. $\S 270.17 d-1$ (a). Although part (a) uses the language "joint enterprise or other joint arrangement or profit sharing plan" rather than "joint or joint and several" as used in section 17(d), 15 U.S.C. $\$ 80 \mathrm{a}-17$ (d) (1976), the regulation, in part (c), defines "joint enterprise or other joint arrangement or profit-sharing plan" as an enterprise or undertaking in which an investment company and an affiliate of the investment company have a "joint or a joint and several" participation, 17 C.F.R. $\$ 270.17 \mathrm{~d}-1$ (c) (1981), and therefore is consistent with section 17(d).

59. See 2 T. Frankel, The Regulation of Money Managers 526 (1978) ("If affiliates use dealings of the investment coinpany over which they have influence to obtain secret benefits, the affiliates are joint participants with the investment coinpany"). See also United States v. Deutsch, 451 F.2d 98 (2d Cir. 1971), cert. denied, 404 U.S. 1019 (1972) (an officer of a registered investment company who made a secret agreement to purchase notes and to receive compensation for a sale of similar notes to an affiliated investment company at a higher price violated section 17(e)); Wellman v. Dickinson, 475 F. Supp. 783, 834 (S.D.N.Y. 1979) (an affiliate of a registered investment company who received secret compensation for participating in the takeover of another firm violated sections 17(d) and 17(e)); SEC v. Commonwealth Chem. Sec., Inc., 410 F. Supp. 1002 (S.D.N.Y. 1976) (investment advisers, acting as underwriters of a separate offering, violated section 17(d) when they caused affiliated investment companies to purchase securities at inflated prices to unload the securities and to protect the advisers' underwriting status); Monheit v. Carter, 376 F. Supp. 334, 341 (S.D.N.Y. 1974) (affiliates of an investment company violated section 17(d) by causing the company's purchase of certificates of deposit (C.D.) to allow the advisers, without the company's knowledge, to obtain loans and advances from the C.D. issuer).

60. 451 F.2d 98 (2d Cir. 1971), cert. denied, 404 U.S. 1019 (1972). 
discount on identical notes purcliased for his personal portfolio. ${ }^{61}$ IIT Manageinent similarly violated section 17 (d) and rule $17 \mathrm{~d}-1$ by influencing IIT to purchase King securities while IIT Management received kickbacks and other benefits from King. ${ }^{62}$

The receipt of kickbacks and other benefits also violated section 17(e). ${ }^{63}$ That section prohibits any affiliated person of an investinent company, "acting as a agent," from receiving any compensation "for the purchase or sale of any property to or for the [investinent company]." 64 The Deutsch court held that the fifty percent discount was unlawful compensation under section 17(e);65 similarly, the kickbacks and other benefits received by IIT Management are the types of compensation that section 17(e) proscribes. ${ }^{66}$

Fimally, IIT Management's activities represented a fraudulent type of scheme unlawful under ICA section 17(j) and rule $17 j-1$. Rule $17 j-1$ makes it an unlawful practice for any affiliated person of a registered investment company, in connection with a sale or purchase of a security held or to be acquired by the investment company, "to employ any device, scheme or artifice to defraud such registered investment company."67 IIT Management, by inducing IIT to purchase securities that IIT Management knew were highly speculative, defrauded IIT in a scheme with the King complex-an act unlawful under ICA section $17(\mathrm{j})$ and rule $17 \mathrm{j}-1$.

IAA section 206 requires an investment adviser to disclose fully any pecuniary imterest that he has in a chent's transactions. ${ }^{68}$ IIT Management's receipt of kickbacks was a pecuniary interest that should have been disclosed under the Act. The SEC has determined that such pecuniary interests prevent an adviser from giving disinterested investment advice to its client. The SEC has stated that

[a]n investment adviser is a fiduciary. As such he is required by the common law to serve the interest of his client with undivided loy-

61. Id. at 106.

62. See IIT v. Cornfeld, 619 F.2d 909, 915 (2d Cir. 1980).

63. 15 U.S.C. $\$ 80 \mathrm{a}-17$ (e)(1) (1976).

64. The phrase "acting as agent," as used in $\S 80 \mathrm{a}-17(\mathrm{e})(1)$, has been given a broad definition that includes all affiliated persons not acting in the capacity of a broker and thus includes IIT Management. See United States v. Deutsch, 451 F.2d at 111.

65. Id. at 107-15.

66. IIT Management's receipt of kickbacks and benefits causes the violation whether or not IIT Management acts upon these payments. See id. at 109-11.

67. 17 C.F.R. $\$ 270.17 \mathrm{j}-1$ (a)(I) (1981).

68. 15 U.S.C. $\$ 80 \mathrm{~b}-6$ (1976). Parts one and two of this section provide that "[i]t shall be unlawful for any investunent adviser . . (1) to employ any device, scheme, or artifice to defraud any client or prospective client; (2) to engage in any transaction, practice, or course of business which operates as a fraud or deceit upon any chent or prospective client." 
alty. . . . [A] breach of his duty may constitute a fraud within the meaning of clauses (1) and (2) of section 206 of the Investment Advisers Act. 69

In addition to violating parts one and two of section 206, failure to disclose a pecuniary interest also violates part four, which makes it unlawful "to engage in any act, practice, or course of business which is fraudulent, deceptive, or manipulative."70

Although IIT Management's activities exemplify the abusive, fraudulent investment, adviser practices that both the ICA and the IAA were created to prevent, the Acts do not apply to IIT Management. ICA section 17 applies only to affiliates of registered investment compames. $^{71}$ IIT was not a registered company and could not register without SEC permission because it was not "organized or otherwise created under the laws of the Umited States or of a state."72 Congress intentionally excluded foreign companies because of potential jurisdictional difficulties. ${ }^{73}$

IAA section 206 applies only to those mvestinent advisers, whether registered or unregistered, who perpetrate their fraudulent acts through the use of interstate commerce. ${ }^{74}$ The extent to which IIT Manageinent or the King complex engaged in interstate commerce is unclear. Moreover, no court has discussed the degree of interstate commerce necessary to support a cause of action under IAA section $206 .{ }^{75}$

69. Investment Advisers Act Release No. IA-40 (Jan. 5, 1945), reprinted in [1981] 5 FED. SEC. L. REP. (CCH) I 56,374. In addition, the SEC stated that

an investment adviser may not effect a transaction as principal with a client unless he obtains the client's consent to the transaction after fully disclosing any adverse interest he may have, together with any other inforination in his possession which the client should possess in order to determine whether he should entcr into the transaction.

Id., [1981] 5 FED. SEC. L. REP. (CCH) \& 56,375. The SEC added that all comments regarding an investment adviser selling for his own account apply when the adviser acts as a broker for a third party. Id., [1981] 5 FED. SEC. L. REP. (CCH) If 56,377.

Note that, unlike rule 10b-5, section 206 of the Investment Advisers Act, 15 U.S.C. \& 80b-6 (1976), requires the adviser to obtain his client's consent in addition to disclosing all material facts. Rule 10 b-5 requires only disclosure of all material facts. See 17 C.F.R. \& 240.10b-5 (1981).

70. 15 U.S.C. § 80b-6(4) (1976).

71. Id. $\$ 80 \mathrm{a}-17$.

72. Id. $\$ 80 \mathrm{a}-8(\mathrm{a})$. See note 73 infra.

73. The Senate Committee on Banking and Currency said that uuder section 7, "[f]oreign investmeut companies may not register as investment companies . . . in the United States unless the Commission finds that these foreign investment companies can be effectively subjected to the sanie type of regulation as domestic investment companies. . . " S. REP. No. 1775, 76th Cong., 3d Sess. 13 (1940). The Commission is given the power to make this determination by 15 U.S.C. $\$ 80 \mathrm{a}-7$ (d) (1976). Only registered investment companies can buy and sell securities in the United States. Id. \& 80a-7(a).

74. Id. $\$ 80 \mathrm{~b}-6$.

75. IIT's origimal complaint included an allegation that section 206 was violated, see IIT v. Cornfeld, 619 F.2d at 914 , but, because neither the district court nor the circuit court discussed the 
Prior to Cornfeld, no court had interpreted any domestic securities regulations to subject a foreign corporation to the high degree of internal regulation advanced by the Second Circuit. An analysis of the court's use of rule 10b-5 extraterritorially and in corporate mismanageinent situations reveals that its use is inappropriate for regulation of internal abuses of investment companies and, even if appropriate when used to regulate internal affairs of offshore investment companies, improperly exceeds prior limits on the extraterritorial application of the securities laws.

\section{Statutory Regulation of OfFshore INVESTMENT COMPANIES: Rule 10b-5}

\section{A. The Relationship Between Rule 10b-5 and IAA Section 206: Disclosure vs. Fiduciary Duty.}

The language of parts a and $c$ of rule $10 \mathrm{~b}-5$ is very similar to that used in parts one, two, and four of IAA section 206. ${ }^{76}$ Although such similarity provides a basis for identical treatment of the statutes, ${ }^{77}$ fun-. damental differences in their supporting policies show that the statutes should not be applied identically.

The SEC adopted rule 10b-5 pursuant to section 10(b) of the Se-

section as a basis for jurisdiction, one must conclude that section 206 was insufficient support for jurisdiction.

76. Rule 10b-5 provides:

It shall be unlawful for any person, directly or indirectly, by the use of any means or instrumentality of imterstate commerce, or of the mails or of any facility of any national securities exchange,

(a) To employ any device, scheine, or artifice to defraud,

(b) To make any untrue statement of a material fact or to omit to state a material fact necessary in order to inake the stateinents made, in the light of the circuinstances under which they were made, not misleading, or

(c) To engage im any act, practice, or course of business whiclı operates or would operate as a fraud or deceit upon any person, in connection with the purchase or sale of any security.

17 C.F.R. § 240.10b-5 (1981).

The pertinent parts of IAA section 206 provide:

It shall be unlawful for any investment adviser, by use of the inails or any ineans or instrumentality of interstate commerce, directly or indirectly-

(1) to employ any device, schcme, or artifice to defraud any client or prospective chient;

(2) to engage in any transaction, practice, or course of busimess which operates as a fraud or deceit upon any client or prospective client;

(4) to engage in any act, practice, or course of business which is fraudulent, deceptive or inanipulative.

15 U.S.C. $\$ 80 \mathrm{~b}-6(1)$, (2), (4) (1976).

77. See, e.g., Transanierica Mortgage Advisors, Inc. v. Lewis, 444 U.S. 11, 25 \& n.1 (1979) (White, J., dissentimg). 
curities and Exchange Act of $1934 .^{78}$ The limited legislative history of section $10(\mathrm{~b})$ and rule $10 \mathrm{~b}-5$ provides no insight into their purpose. ${ }^{79}$ In contrast, the legislative history of IAA section 206, though also limited, reveals a major purpose of that section: to create fiduciary standards for the investment adviser. ${ }^{80}$ Although courts have continuously expanded interpretations of rule $10 \mathrm{~b}-5$ 's purpose, ${ }^{81}$ they have consistently followed the congressional expression of intent that IAA section 206 should apply to the fiduciary relations between investment advisers and their chents. 82 Certam activities involving investment advisers and their chents probably fall within the wide range of actions covered by rule $10 \mathrm{~b}-5$, yet extraterritorial application of rule $10 \mathrm{~b}-5$ to regulate fiduciary activities of investment advisers would be contrary to Con-

\section{15 U.S.C. $\$ 78 \mathrm{j}$ (1976).}

79. The only specific reference to section $10(\mathrm{~b})$ is in a Senate report stating that the section "was aimed at those manipulative and deceptive practices which have been demonstrated to fulfill no usefnl function." S. Rep. No. 792, 73d Cong., 2d Sess. 6 (1934). The Supreme Court has expressly noted the lack of legislative history on section 10(b): "Neither the intended scope of $\S 10$ (b) nor the reasons for the changes in its operative language are revealed explicitly in the legislative history of the 1934 Act, which deals primarily with other aspects of the legislation." Ernst \& Ernst v. Hochfelder, 425 U.S. 185, 202 (1976).

Milton Friedman, one of the drafters of rule $10 \mathrm{~b}-5$, described the events leading to the rule's creation and adoption:

It was one day in the year 1943, I believe. I was sitting in iny office in the S.E.C. building in Philadelphia and I received a call from Jim Treanor who was then the Director of the Trading and Exchange Division. He said, "I have just been on the teleplione with Paul Rowen," who was then the S.E.C. Regional Administrator in Boston, "and he lias told Ine abont the president of some company in Boston who is going around buying up the stock of his company from his own shareholders at $\$ 4.00$ a share, and he has been telling them that the company is doing very badly, whereas, in fact, the earnings are going to be qnadrupled and will be $\$ 2.00$ a share for this coming year. Is there anything we can do about it?" So he came npstairs and I called in iny secretary and I looked at Section 10(b) and I looked at Section 17, and I pnt them together, and the only discussion we lad there was where "in connection with the purchase or sale" shonld be, and we decided it sliould be at the end.

We called the Commission and we got on the calendar, and I don't remeinber whether we got there that morning or after lunch. We passed a piece of paper around to all the commissioners. All the commissioners read the rule and they tossed it on the table, indicating approval. Nobody said anything except Sumner Pike who said, "Well," he said, "we are against frand, aren't we?" That is how it happened. pened.

... I never thought that . . . later it would be the biggest thing that liad ever hap-

Conference on Codification of the Federal Securities Laws, 22 Bus. LAw. 793, 922 (1967).

80. See S. REP. No. 1775, 76th Cong., 3d Sess. 21-22 (1940). See notes 41-49 supra and accompanying text.

81. See, eg., Goldberg v. Meridor, 567 F.2d 209 (2d Cir. 1977), cert. denied, 434 U.S. 1069 (1978); Schoenbaum v. Firstbrook, 405 F.2d 200 (2d Cir.), rev'd with respect to holding on merits, 405 F.2d 215 (2d Cir. 1968) (en banc), cert. denied, 395 U.S. 906 (1969).

82. See, eg., Transamerica Mortgage Advisors, Inc. v. Lewis, 444 U.S. 11 (1979) (applying IAA section 206); SEC v. Capital Gains Research Bureau, 375 U.S. 180 (1963) (applying IAA section 206). 
gress's intent, expressed in the IAA, to limit such regulation to domestic activities. ${ }^{83}$

The basic purposes of rule $10 \mathrm{~b}-5$ are to protect marketplace integrity and to equalize inarket risk to investors by requiring full disclosure of all information material to the purchase or sale of securities. ${ }^{84}$ The rule regulates the environment in which securities are bought and sold by promoting equal access to material inforination for all investors. ${ }^{85}$ Although IAA section 206 also requires full disclosure by imvestment advisers, its purpose is not protection of marketplace integrity or equalization of investor risk; its purpose is to protect client expectations that the investment adviser will fulfill its fiduciary duty in advising the client. ${ }^{86}$ The Supreme Court has stated that section 206 "reflects a congressional recognition 'of the dehcate fiduciary nature of an investment advisory relationship,' as well as a congressional intent to eliminate, or at least to expose, all conflicts of interest." 87 Therefore, although both rule 10b-5 and section 206 are disclosure-oriented, the different purposes for which the disclosure is required reveal fundamental pohicy differences underlying the laws.

Judicial application of rule 10b-5 and IAA section 206 has also revealed their basic policy differences. In Santa Fe Industries, Inc. $v$. Green $^{88}$ the Supreine Court refused to extend the scope of rule 10b-5 to mclude a mere breach of fiduciary duty that involved neither deception nor manipulation. The Court feared that such an extension would bring a wide variety of corporate conduct, which had typically been regulated by the states as breach of fiduciary duty, within the scope of rule 10b-5.89 The Court was reluctant to allow federal courts to override established state policies of corporate regulation for the purpose of applying a uniform "federal fiduciary principle."90

83. See text accompanying notes 50-52 supra.

84. "A major purpose of the [securities laws is] to "protect the integrity of the marketplace in which securities are traded." United States v. Chiarella, 588 F.2d 1358, 1365 (2d Cir. 1978), rev'd, 445 U.S. 222 (1980).

[T]he Rule is based in policy on the justifiable expectation of the securities marketplace that all investors trading on impersonal exchanges lave relatively equal access to material information.

$\cdots$

The core of Rule $10 \mathrm{~b}-5$ is the implementation of the Congressional purpose that all investors should have equal access to the rewards of participation in securities transactions. It was the intent of Congress that all members of the investing public should be subject to identical market risks.

SEC v. Texas Gulf Sulphur Co., 401 F.2d 833, 848, 851-52 (2d Cir. 1968).

85. 401 F.2d at 848.

86. See SEC v. Capital Gains Researclı Bureau, Inc., 375 U.S. 180 (1963).

87. Id. at 191 .

88. 430 U.S. 462 (1977).

89. Id. at 478 .

90. Id. at 479 . 
In contrast, Congress deemed the fiduciary relationship between investment advisers and their chents appropriate for national regulation. ${ }^{91}$ The Supreme Court has consistently held that IAA section 206 creates "federal fiduciary standards" for investment advisers. ${ }^{92}$ In addition, the Supreme Court recently refused to infer a private right of action from IAA section $206^{93}$ although the existence of imphed private rights of action under rule $10 \mathrm{~b}-5$ is well established. ${ }^{94}$ A possible, albeit implicit, reason for the Court's refusal to infer a private right of action may be reluctance to allow such actions under a statute imposing major controls on the internal, fiduciary affairs of investment advisers. ${ }^{95}$

Rather than examining the policies underlying the disclosure requirements of rule 10b-5 and of IAA section 206, the Second Circuit in Cornfeld assumed rule 10b-5 was applicable and ignored the basis of IIT's complaimt, IIT Management's breach of fiduciary duty. The action was based on IIT Management's failure to disclose its financial interest in the King-coinplex transactions. Disclosure of such an interest does not fulfill rule 10b-5 policies of equal investor information or increased market integrity but, by revealing a conflict of interest detrimental to the fiduciary relationship between IIT and IIT Management, fulfills the policies underlying IAA section 206. By characterizing IIT Management's activities as a rule 10b-5 violation, the Cornfeld court ignored rule $10 \mathrm{~b}-5$ 's policy basis.

\section{B. Rule 10b-5 and Fiduciary Duty: Goldberg v. Meridor.}

1. Breach of Fiduciary Duty as a Basis for Rule 10b-5 Actions. To use rule 10b-5 in Cornfeld, the court applied a Second Circuit doctrine that characterizes a breach of fiduciary duty as a material fact and that makes failure to disclose this fact to a corporation's noninterested directors or investors a deceptive act violating rule 10b-5.96 The Second Circuit first considered a $10 \mathrm{~b}-5$ action involving breach of fiduciary

91. 15 U.S.C. $\$ 80 b-1$ (1976).

92. See Transamerica Mortgage Advisors, Inc. v. Lewis, 444 U.S. 11,17 (1979); SEC v. Capital Gains Research Bureau, 375 U.S. 180, 191 (1963).

93. 444 U.S. at 24.

94. See, e.g., Superintendent of Ins. v. Bankers Life \& Cas. Co., 404 U.S. 6, 13 n.9 (1971).

95. Although the Court did not express this rationale as a basis for its holding, it prefaced its discussion of the implied right of action with a review of the fiduciary nature of section 206.444 U.S. at 17.

96. See Goldberg v. Meridor, 567 F.2d 209 (2d Cir. 1977), cert. denied, 434 U.S. 1069 (1978). Three other courts of appeals have adopted rationales similar to that of Goldberg. See Healey v. Catalyst Recovery of Pa., Inc., 616 F.2d 641, 645 (3d Cir. 1980); Kidwell v. Meikle, 597 F.2d 1273, 1291-92 (9th Cir. 1979); Wright v. Hcizer Corp., 560 F.2d 236, 250 (7th Cir. 1977), cert. denied, 434 U.S. 1066 (1978). 
duty in Schoenbaum v. Firstbrook,,$^{97}$ in which a parent corporation induced its subsidiary to sell 500,000 shares of treasury stock to the parent before it released information of a valuable oil discovery. ${ }^{98}$ The court held that exercise of "controlling influence" over a subsidiary is a deceptive act under rule $10 \mathrm{~b}-5.99$ The court also implicitly held that, when all directors of a subsidiary are parties to the fraud, the knowledge of the directors is not imputed to the subsidiary. 100

In 1977 the Supreme Court, in Santa Fe Industries, Inc. v. Green, ${ }^{101}$ reversed a Second Circuit decision that allowed an action under rule $10 \mathrm{~b}-5$ for breach of fiduciary duty absent deceptive or mamipulative acts. The Court held that Congress, by enacting section $10(b),{ }^{102}$ did not intend to prohibit conduct not involving manipulation or deception ${ }^{103}$ and that "manipulation" as a term of art does not include corporate mismanagement. ${ }^{104}$ In addition, the Court expressed reluctance to extend federal regulation to an area traditionally governed by state law. 105 The Green decision appeared to end the trend toward application of rule $10 \mathrm{~b}-5$ to actions involving a breach of fiduciary duty.

Three months after the Green decision, the Second Circuit, in Goldberg v. Meridor, ${ }^{106}$ reconsidered the Schoenbaum "controlling influence" doctrine in light of Green. In Goldberg a parent corporation caused one of its successful subsidiaries to assume the overvalued assets and massive habilities of a troubled subsidiary and issued four million of the successful subsidiary's shares to the troubled subsidiary. The result was a reduction of the successful subsidiary's assets for the benefit of the troubled subsidiary and the parent. ${ }^{107}$ A shareholder of the

97. 405 F.2d 200 (2d Cir.), rev'd with respect to holding on merits, 405 F.2d 215 ( $2 \mathrm{~d}$ Cir. 1968) (en banc), cert. denied, 395 U.S. 906 (1969).

98. The parent acquired the shares for $\$ 1.35$ per share. After the oil discovery was disclosed, the shares sold for as much as $\$ 18$ per share. See 405 F.2d at $205 \&$ n.1.

99. Id. at 219-20.

100. See id. at 220.

101. 430 U.S. 462 (1977).

102. 15 U.S.C. \& 78j (1976).

103. 430 U.S. at $472-74$.

104. Id. at 476-77.

105. Id. at $477-78$.

106. 567 F.2d 209 (2d Cir. 1977), cert. denied, 434 U.S. 1069 (1978). Green was decided on March 23, 1977. Goldberg was argued on June 9, 1977. In an apparent attempt to avoid a dismissal under Green by claiming an element of deception, the plaintiff in Goldberg appealed from the district court's refusal to allow him to amend his complaint with evidence of misleading press releases. The circuit court granted leave to amend. 567 F.2d at 213.

107. Id. at 211. In Goldberg a shareholder of Universal Gas \& Oil Coinpany (UGO) brought a derivative action against UGO's controlling parent, Maritimecor, and Maritimecor's parent, Maritime Fruit Carriers. The complaint alleged that the defendants violated rule $10 \mathrm{~b}-5$ by causing UGO to enter into an agreement with Maritimecor in which UGO issued to Maritimecor over 
successful subsidiary brought a derivative action in which he alleged that, in hight of two misleading press releases issued by the parent, the actions of the parent and of the troubled subsidiary violated rule 10b5.108 The Second Circuit, concluding that the case was a Schoenbaum breach of fiduciary duty situation, held that Green did not overrule Schoenbaum and that

Schoenbaum ... can rest solidly on the now widely recognized ground that there is deception of the corporation ... . when the corporation is influenced by its controlling shareholder to engage in a transaction adverse to the corporation's interests ... and there is nondisclosure or misleading disclosures as to the inaterial facts of the transaction. ${ }^{109}$

Although the directors of the successful subsidiary knew of the fraudulent activities, the court refused to impute the directors' knowledge to this subsidiary, instead viewing the fraud as though "independent stockholders were standing in the place of the defrauded corporate entity."110

The practical effects of Goldberg are to revive the Schoenbaumtype action for breach of fiduciary duty and to evade the Green limitation on such actions by making the breach a material fact that, under rule 10b-5, must be disclosed."11 Because "[t]hose who breach their fiduciary duties seldom disclose their intentions ahead of time,"112 Goldberg brings almost all breaches of fiduciary duty, matters traditionally left to the states, within the scope of rule $10 b-5 .{ }^{113}$

2. The Effect of Goldberg on Investment Company Regulation. By using the expanded scope of rule 10b-5 under Goldberg, courts can

four million shares of UGO stock and assumed all Maritimecor's liabilities (including a seven million dollar debt owed to UGO) in exchange for all Maritimecor assets. Maritime Fruit and Maritimecor allegedly overvalued the assets of Maritimecor to cause "the dissipation of the substantial assets of UGO for the benefit of . . . Maritimecor and Maritime Fruit." Id. After the transaction, the defendant corporations issued two press releases that "held out an inviting picture" of future growth and success. $I d$. at $214 \&$ n. 4 .

108. Id.

109. Id. at 217.

110. Id. at 215-16. See Schoenbaum v. Firstbrook, 405 F.2d 200, 211-14 (2d Cir.), rev'd on other grounds, 405 F.2d 215 (2d Cir. 1968) (en banc), cert. denied, 395 U.S. 906 (1969); Pappas v. Moss, 393 F.2d 865, 869 (3d Cir. 1968).

111. See TSC Indus., Inc. v. Northway, Inc., 426 U.S. 438 (1976).

112. Goldberg v. Meridor, 567 F.2d at 225 (Meskill, J., dissenting).

113. "[S]ave for those rare instances where the fiduciary denounces himself." Id. To avoid conflict with the Supreme Court's decision in Green, the Goldberg rationale may be applied only when a state law cause of action exists for the nondisclosed action. Otherwise, Goldberg would constitute the type of regulation of fiduciary duty rejected in Green. Compare Santa Fe Indus., Inc. v. Green, 430 U.S. 462 (1977) with Goldberg v. Meridor, 567 F.2d 209 (2d Cir. 1977), cert. denied, 434 U.S. 1069 (1978). 
regulate the internal investment decisions of any investment company, whether foreign or domestic, and ignore the anti-fraud provisions of the ICA and the IAA. ${ }^{114}$ Because the duties of an investinent adviser focus primarily on the sale and purchase of securities for the investment company's portfoho, any questionable activities regarding those duties, excludimg theft or embezzlement of investment coinpany funds, can be addressed under rule $10 \mathrm{~b}-5$. For example, rather than determine whether a party to an investment company is "affiliated"115 or is a "joint and several" 116 participant in the transaction, a court need only determine that the party's interests were "inaterial" to the transaction and, thus, should have been disclosed. ${ }^{117}$ The court's focus shifts from regulation of investment company mismanageinent to protection of investors and securities markets. By expanding the scope of rule $10 \mathrm{~b}-5$ to cover internal mismanagement of investment companies, the Second Circuit has threatened the viability of the ICA and the IAA, Acts specifically designed to regulate those internal abuses. Actions prohibited by the ICA and the IAA probably always satisfy the $10 b-5$ materiahity test, because ICA and IAA regulation of those actions is, arguably, conclusive proof of materiality. Regulation of doinestic investment coinpanies through rule $10 \mathrm{~b}-5$ is harmless: the court merely arrives at a similar result using a different statute. In contrast, regulation of the internal affairs of foreign investment companies through extraterritorial application of rule 10b-5 remains within the substantive limits of the ICA and IAA, but greatly exceeds the express jurisdictional limits of those Acts. ${ }^{118}$

114. See notes 54-74 supra and accompanying text.

115. See 15 U.S.C. $\$ 80 a-17$ (1976). ICA section 17 prohibits "affiliated persons" of investment companies from engaging in various types of transactions with those investment companies. Section 2(a)(3) of the ICA defines "affliated person":

(3) "Affiliated person" of another person means (A) any person directly or indirectly owning, controlling, or holding with power to vote, 5 per centum or more of the outstanding voting securities of such other person; (B) any person 5 percentum or inore of whose outstanding voting securities are directly or imdirectly owned, controlled, or held with power to vote, by such other person; (C) any person directly or imdirectly controlling, controlled by, or under common control with, such other person; (D) any officer, director, partner, copartner, or employee of such other person; (E) if such other person is an investment company, any investinent adviser thereof or any member of an advisory board thereof; and (F) if such other person is an unincorporated investinent company not having a board of directors, the depositor thereof.

15 U.S.C. \& 80a-2(a)(3) (1976).

116. ICA section 17(d) prohibits an affiliated person from participating with the imvestment company, on a joint and several basis, in any transactions. 15 U.S.C. \& 80a-17(d) (1976). For examples of activities that would violate this section, see text accompanying notes 54-62 supra.

117. Information is "inaterial" if there exists "a substantial likelihood that, under all the circumstances, the omitted fact would have assumed actual significance in the deliberations of the reasonable shareholder." TSC Indus., Inc. v. Northway, Inc., 426 U.S. 438, 449 (1976).

118. See notes 50-52 \& 74 supra and accoinpanying text. 


\section{Extraterritorial Application of Rule 10b-5.}

As a basis for asserting subject-1natter jurisdiction over matters occurring outside the United States, American courts often refer to the RESTATEMENT (SECOND) OF FOREIGN RELATIONS LAW OF THE UNITED STATES. ${ }^{119}$ The Restatement provides for broad jurisdiction that may be based either on conduct occurring within United States territory, the "conduct" test, ${ }^{120}$ or on conduct occurring outside that territory but having substantial effects within that territory, the "effects" test. ${ }^{121}$ Judicial interpretation of rule 10b-5 has led to extraterritorial application of the rule based on narrow versions of the Restatement's effects and conduct tests.

The Second Circuit created the foundation for the effects test in Schoenbaum v. Firstbrook, 122 in which it stated that "Congress imtended the Exchange Act to have extraterritorial apphication in order to protect . . . the doinestic securities market from the effects of improper foreign transactions in American securities." 123 This broad version of the effects test, applicable to almost any foreign transaction related to American investors or securities markets, was substantially limited in two subsequent cases. In Leasco Data Processing Equipment Corp. $v$. $M^{M a x w e l l}{ }^{124}$ the Second Circuit, concluded that Congress did not intend "to impose rules governing conduct throughout the world in every imstance where an American company bought or sold a security"125 and

119. See, e.g., Bersch v. Drexel Firestone, Inc., 519 F.2d 974 (2d Cir.), cert. denied, 423 U.S. 1018 (1975); IIT v. Vencap, Ltd., 519 F.2d 1001 (2d Cir. 1975); Leasco Data Processing Equip. Corp. v. Maxwell, 468 F.2d 1326 (2d Cir. 1972).

120. Restatement (SECOND) OF THE Foreign ReLAtions LAW of the UNITEd STATES \& 17 (1965) provides:

A state has jurisdiction to prescribe a rule of law

(a) attaching legal consequences to conduct that occurs within its territory, whether or not such consequences are determined by the effects of the conduct outside the territory, and

(b) relating to a thing located, or a status or other interest localized, in its territory.

121. Section 18 of the RESTATEMENT provides:

A state has jurisdiction to prescribe a rule of law attaching lcgal consequences to conduct that occurs outside its territory and causes an effect within its territory, if either

(a) the couduct and its effect are generally recognized as constituent eleinents of a crime or tort under the law of states that have reasonably developed legal systems, or

(b)(i) the conduct and its effect are constituent elements of activity to which the rule apphies; (ii) the effect within the territory is substantial; (iii) it oceurs as a direct and foreseeable result of the conduct outside the territory; and (iv) the rule is not inconsistent with the principles of justice generally recognized by states that have reasonably developed legal systems.

122. 405 F.2d 200 ( $2 \mathrm{~d}$ Cir.), rev'd with respect to holding on merits, 405 F.2d 215 (en banc), cert. denied, 395 U.S. 906 (1969).

123. 405 F.2d at 206.

124. 468 F.2d 1326 (2d Cir. 1972).

125. Id. at 1334 . 
implied that the effect of the foreign transaction must be substantial. ${ }^{126}$ Later, in Bersch v. Drexel Firestone, Inc. ${ }^{127}$ the court further limited the effects test by holding that the test applies only to acts causing direct injury to purchasers or sellers in whoin the United States has an interest. Therefore, courts obtam subject-1natter jurisdiction over transactions occurring outside the United States only if the transactions have a substantial and direct effect on persons in whon the United States has an interest.

The "conduct" test was first applied in Leasco Data Processing Equipment Corp. v. Maxwell, ${ }^{128}$ in which the court took subject-nratter jurisdiction over nondoinestic, fraudulent acts induced by substantial misrepresentations in the United States. ${ }^{129}$ The court interpreted the conduct test broadly, finding misrepresentation in actions that were preparatory to the crucial, fraudulent acts that occurred abroad. The Second Circuit, in IIT v. Vencap, Ltd., ${ }^{130}$ later narrowed the test, requiring that fraudulent misrepresentations, not nerely preparatory acts, occur in the United States. Therefore, a court has subject-inatter jurisdiction under the conduct test if a nondoinestic, fraudulent transaction is induced by substantial, fraudulent misrepresentations occurring in the United States.

The transactions at issue in IIT v. Cornfeld do not satisfy the effects test. ${ }^{131}$ First, the transactions produced only generalized effects on the American econonty, allegedly inaking it difficult for American corporations to attract offshore investinent funds 132 -effects similar to those rejected in Bersch for lack of directness and substantiahty. ${ }^{133}$

126. See id. at $1334-35$.

127. 519 F.2d 974, 989 (2d Cir.), cert. denied, 423 U.S. 1018 (1975). See note 130 infra.

128. 468 F.2d 1326 (2d Cir. 1972).

129. Id. at 1337.

130. 519 F.2d 1001, 1018 (2d Cir. 1975). Vencap was decided concurrently with a similar extraterritorial jurisdiction case, Bersch v. Drexel Firestone, Inc., 519 F.2d 974 (2d Cir.), cert. denied, 423 U.S. 1018 (1975). In Bersch a large class of predominantly foreign investors sued to recover losses resulting from the purchase of shares of Investors Overseas Services (IOS), a Canadian corporation. The complaint alleged that $1 O S$ and several underwriter defendants (including Drexel Firestone, an American banking house) issued a prospectus for the initial offering of $10 \mathrm{~S}$ stock that materially misrepresented the financial status of IOS. The prospectuses were distributed to foreign imvestors and the offering was restricted to areas not subject to United States jurisdiction. Emphasizing the obvious lack of substantial activities in the United States, the court refused to extend apphication of rule $10 \mathrm{~b}-5$ "to cases where the United States activities are merely preparatory or take the form of culpable nonfeasance and are relatively small in comparison to those abroad." 519 F.2d at 987. Although the court's analysis implies an intentional shift away from a test requiring substantial domestic misrepresentations to one requiring only substantial domestic activities, that unphication was negated in Vencap, 519 F.2d at 1018.

131. 619 F.2d 909, 917 (2d Cir. 1980).

132. Id.

133. See 519 F.2d at $987-88$. 
Second, the transactions had only an indirect effect on American investors because the injured parties had no substantial connection with the United States. ${ }^{134}$

Even though the effects test was not inet, the Cornfeld court held that subject-matter jurisdiction existed under the conduct test. The court faced a problem in applying the conduct test, because there were no IIT Managenıent activities in the United States. The only domestic, fraudulent activities were those of the King complex, persons not parties to the litigation. By applying Goldberg $v$. Meridor, ${ }^{135}$ the court . transformed the case from one involving IIT Management's breach of fiduciary duty to one characterized as a conspiracy between IIT Management and the King complex. ${ }^{136}$ Although the former is not actionable under rule $10 \mathrm{~b}-5,137$ the later "conspiracy" formulation is actionable under 10b-5. The court then linked IIT Management to the domestic activities of the King complex to establish the domestic conduct necessary for subject-nuatter jurisdiction. ${ }^{138}$ The result was expo-

134. See note 147 infra.

135. 567 F.2d 209 (2d Cir. 1977), cert. denied, 434 U.S. 1069 (1978). See notes 106-13 supra and accompanying text.

136. 619 F.2d at $917-18$.

137. Mcre breach of fiduciary duty is an insufficient basis for 10b-5 liability. See Santa Fe Indus., Inc. v. Green, 430 U.S. 462 (1977).

138. 619 F.2d at 917-18. The court had hittle difficulty estabhshing the requisite conduct for subject-matter jurisdiction over the KRC stock purchase and the TCC note purchase (for a description of the transactions, see text accompanying notes $18 \& 19$ supra). Because the securities were of American corporations and lad been purcliased in the United States by Lipper, IIT's American broker, the court reasoned that federal antifraud regulations should apply to the transactions. 619 F.2d at 918-19. The court found subject-matter jurisdiction over the KRCC convertible-debenture transaction more difficult because the entire transaction liad been consummated in Europe. The defendants argued that the transaction fell within the dicta in Bersch v. Drexel Firestone, Inc., 519 F.2d 974, 993 (2d Cir.), cert. denied, 423 U.S. 1018 (1975), that the federal securities laws do not apply to losses from foreign sales of securities unless the losses are directly caused by acts occurring within the United Statcs. 519 F.2d at 919 . The court distinguished Bersch, concluding that the KRCC debentures were essentially the obligations of KRC and that the acts performed in the United States were inuch inore than mere preparatory acts. Id. at 91920. The court distinguished Bersch on three grounds. First, unlike Cornfeld, the Bersch transactions involved only foreign securities. Judge Friendly reasoned that although the KRCC debentures were sold in Europe, they were the financial obhgations of a United States corporation because they were guaranteed by an American corporation (KRC), were convertible into KRC common stock, and were issucd by a foreign subsidiary (KRCC) that had no operating assets and that was created by its American parent (KRC) only to help foreign investors avoid paying United States withholding tax on interest payments. Id. Second, Judge Friendly noted the 'relatively greater participation of an American investunent house as the lead underwriter of the KRC debenture offering and as the co-lead underwriter of the eurodollar offering. Id. at 920. Finally, he asserted that because the KRCC debentures were essentially obligations of an American corporation, the activities occurring in the Unitcd States were much more than the nere preparatory activities in Bersch. He focused on the drafting, accounting work, and printing of the prospectus, all performed in the Umitcd States, for both the domestic offering and the foreign offering, and concluded that '[d]etermination whether American activities 'directly' caused losses to foreigners 
sure of an offshore investunent company to regulatory control that not only exceeded all prior extensions of the ICA and IAA, but also exceeded all prior extraterritorial extensions of rule 10b-5.

In all pre-Cornfeld cases applying rule 10b-5 extraterritorially through the conduct test, the fraudulent misrepresentations occurred in the United States. The activities in Cornfeld occurred outside the United States and are thus distinguishable. For example, in Leasco ${ }^{139}$ representatives of a British company net with and niade misrepresentations to Leasco in New York, ${ }^{140}$ and in Vencap ${ }^{141}$ the director of a Bahamian investment fund, by using corporate funds for personal niatters, defrauded the fund from his New York office. ${ }^{142}$ In contrast, the conduct test was not satisfied in Bersch ${ }^{143}$ because the deceptive acts occurred only in foreign countries and "merely preparatory" acts occurred in the Umited States. ${ }^{144}$

In Cornfeld the court misdirected its analysis of conduct, focusing on the conduct of the King coniplex rather than on that of IIT Manageinent. IT Management's liability was established under the rationale of Goldberg: ${ }^{145}$ the deception occurred because IIT Management, as controlling shareholder, influenced IIT, the corporation, to engage in

depends not only on how much was done in the United States but also on how much (here how hittle) was done abroad." Id. at 920-21.

139. 468 F.2d 1326 (2d Cir. 1972).

140. Id. at 1330-33, 1334-35.

141. 519 F.2d 1001 (2d Cir. 1975).

142. Id. at 1008 .

143. 519 F.2d 974 (2d Cir.), ccrt. denied, 423 U.S. 1018 (1975).

144. Id. at 987. Several courts have discussed extraterritorial application of rule 10b-5. See, eg., Continental Grain (Austl.) Pty. Ltd. v. Pacific Oilseeds, Inc., 592 F.2d 409 (8th Cir. 1979); SEC v. Kasser, 548 F.2d 109 (3d Cir. 1977); Straub v. Vaisman \& Co., 540 F.2d 591 (3d Cir. 1976); IIT v. Vencap, Ltd., 519 F.2d 1001 (2d Cir. 1975); Travis v. Anthes Imperial, Ltd., 473 F.2d 515 (8th Cir. 1973); Schoenbaum v. Firstbrook, 405 F.2d 200 (2d Cir.), rev'd with respect to holding on merits, 405 F.2d 215 (2d Cir. 1968) (en banc), cert. denied, 395 U.S. 906 (1969); Selzer v. Bank of Bermuda Ltd., 385 F. Supp. 415 (S.D.N.Y. 1974); SEC v. Gulf Intercontinental Fin. Corp., 223 F. Supp. 987 (S.D. Fla. 1963). Sce generally Mizrack, Recent Developments in the Extraterritorial Application of Section 10(b) of the Securities and Exchange Act of 1934, 30 Bus. LAw. 367 (1975); Note, Offshore Mutual Funds: Extraterritorial Application of the Securities Exchange Act of 1934, 13 B.C. INDus. \& CoM. L. REv. 1225 (1972); Note, Extraterritorial Application of the Securities Exchange Act of 1934, 69 CoLuM. L. REv. 94 (1969); Note, The Extraterritorial Application of the Antifraud Provisions of the Securities Acts, 11 CoRNELL INT'L L.J. 137 (1978); Note, Amerlcan Adjudication of Transnational Securities Fraud, 89 HARv. L. REv. 553 (1976); Note, Securities Laws-Subject Matter Jurisdiction in Transnational Securities Fraud, 9 N.Y.U.J. INT'L L. \& PoL'Y 113 (1976); Note, Extra Territorial Application of Section 10(b) and Rule 10b-5, 34 OHIO ST. L.J. 342 (1973); Comment, The Transnational Reach of Rule 10b-5, 121 U. PA. L. REv. 1363 (1973); Note, Extraterritorial Application of \$ 101b) of the Securities Exchange Act of 1934 -The Implications of Bersch v. Drexel Firestone, Inc. and IIT v. Vencap, Ltd., 33 WASH. \& LEE L. REV. 397 (1976); Comment, 6 BRoOKLYN J. INT'L L. 156 (1980); Case Comment, 7 DEN. J. INT'L L. \& POL'Y 279 (1977).

145. 567 F.2d 209 (2d Cir. 1977), cert. denied, 434 U.S. 1069 (1978). 
transactions adverse to IIT's interests without disclosing IIT Management's pecuniary interest, a fact material to the transaction. ${ }^{146}$ Viewed in this light, the fraudulent, domestic misrepresentations required under the conduct test could not liave occurred. Because IlT Management and the IIT fundholders were all foreign citizens, and all activities between IIT Management and IIT occurred abroad, ${ }^{147}$ the deception required for Goldberg liability-nondisclosure of IIT Management's pecuniary interest-necessarily occurred abroad. ${ }^{148}$ Therefore, the Second Circuit incorrectly applied Goldberg and should not lave applied rule $10 \mathrm{~b}-5$.

Even if the Second Circuit's basis for applying rule $10 \mathrm{~b}-5$ in Cornfeld is valid, application of the rule achieves none of the rule's purposes. Furthermore, sucl application assumes an interpretation of rule 10b-5 that exceeds the rulemaking power granted in Securities Exchange Act section 10(b). ${ }^{149}$ Rule 10b-5 was adopted pursuant to section 10(b) as one of "the rules and regulations . . the [SEC] may prescribe as necessary or appropriate in the public interest or for the protection of investors." 150 The Cornfeld transactions had insubstantial effects on domestic securities markets, ${ }^{151}$ and thus liad little or no effect on the public interest.

Similarly, the potential $10 \mathrm{~b}-5$ liability created by Cornfeld does not increase investor protection. Under Cornfeld a foreign investment adviser may be held liable for the domestic activities of an American corporation if the adviser fails to disclose its pecuniary interest in the sale of the corporation's securities to its client. If the adviser makes the requisite disclosure, the fiduciary relationship is preserved, but the client still is exposed to fraud arising from the doinestic activities of the American corporation. When the investment adviser also has knowledge of the corporation's fraudulent activities, Cornfeld requires disclosure of that information to protect foreign investors. Protection of

146. IIT v. Cornfeld, 619 F.2d at 917-18.

147. Pursuant to a consent agreement that resulted from a prior SEC enforcement action against Bernard Cornfeld and Investors Overseas Services (IOS), the parent corporation of IIT, IOS agreed not to sell shares of IIT in any area within SEC jurisdiction and also agreed to repurchase IIT shares from United States citizens then holding them. Sccurities Exchange Act Release No. 8083 (May 23, 1967). Regardless of the consent agreement, of the 144,496 fundholders of IIT, approximately 218 were United States residents. ITT v. Cornfeld, 462 F. Supp. 209,212 (S.D.N.Y. 1978), rev'd, 619 F.2d 909 (2d Cir. 1980). These domestic fundholders may have been scrvicemen who purchased the shares while overseas. 462 F. Supp. at 212 n.5. Both courts agreed that this small number of domestic fundholdcrs had little effect on the case. See id. at 223;619 F.2d at 917 .

148. IIT v. Cornfeld, 462 F. Supp. 209 (S.D.N.Y. 1978), rev'd, 619 F.2d 609 (2d Cir. 1980).

149. 15 U.S.C. \& 78j (1976).

150. $I d . \S 78 \mathrm{j}(\mathrm{b})$.

151. See IIT v. Cornfeld, 619 F.2d at 917 . See note 147 supra. 
foreign investors by discouraging fraudulent activities of a foreign investment adviser, however, does not fulfill the purposes of rule 10b-5 because fraud by a foreign investment adviser is a situation in which apphicable foreign laws should goveru.

All pre-Cornfeld cases that apply rule $10 \mathrm{~b}-5$ extraterritorially seek to protect foreign investors against fraudulent activities perpetrated by individuals inside the United States. ${ }^{52}$ Application of rule 10b-5 in Cornfeld protects foreign investors of IIT against the fraudulent activities of their foreign investment adviser, IIT Managenent. ${ }^{153}$ Application of the rule to the Cornfeld situation necessarily extends the rule beyond section $10(\mathrm{~b})$ by providing protection to foreign investors against foreign, fraudulent acts. A similar extension of rule $10 \mathrm{~b}-5$ was rejected in Leasco Data Processing Equipment Corp. v. Maxwell, ${ }^{154}$ in which the Second Circuit concluded that rule 10b-5 does not apply to every transaction in which an American corporation buys or sells securities. The court should have similarly rejected the extension in Cornfeld.

\section{ConClusion}

The use of rule $10 \mathrm{~b}-5$ to regulate offshore investment companies at first appears logical, but, after careful analysis of the pohicy implications and repercussions of such use, rule $10 \mathrm{~b}-5$ clearly is inappropriate. IIT v. Cornfeld is an example of the intrusive regulation that results from blind application of rule 10b-5 without the necessary policy analysis. By exercising subject-1natter jurisdiction in Cornfeld, the Second Circuit further extended the already broad scope of rule 10b-5. By applying rule 10b-5 extraterritorially to a Goldberg-type situation involvmg misleading disclosures closely related to a breach of fiduciary duty, the court not only increased the geographical application of the rule, but also increased the types of foreign activities covered by the rule. The decision exposes all directors and advisers of offshore investment companies dealing in the securities of United States corporations to potential liability under rule $10 \mathrm{~b}-5$.

Although the extension of rule $10 \mathrm{~b}-5$ sanctions to transactions involving foreign deception of doinestic investors or domestic deception of foreign investors is acceptable, the extraterritorial apphication of rule $10 \mathrm{~b}-5$ to actions involving foreign deception of foreign investors is unacceptable. Such application of rule $10 \mathrm{~b}-5$ is an intrusion into the

152. See notes $139-44$ supra and accompanying text.

153. See IlT v. Cornfeld, 462 F. Supp. at 223.

154. 468 F.2d 1326, 1334 (2d Cir. 1972). 
wholly foreign operations of a foreign fiduciary fulfilling its obligations to its foreign shareholders. Congress, in the ICA and the IAA, explicitly refused to regulate those foreign fiduciary relationships. The court has no power to extend other sections of the federal securities laws to accomplish the exact regulation rejected by Congress. Despite this lack of power, the Second Circuit has performed such an extension and has created a situation it had previously sought to avoid, one in which American securities regulations govern conduct of any party, whether domestic or foreign, in every instance in which an American corporation buys or sells a security. ${ }^{155}$

Steven L. Hearn

155. See id. 